\title{
Protection status assessment, prospects and methods of conservation of species of Schivereckia (Draba s. I.; Brassicaceae) in Ukraine
}

\author{
Alexander KAGALO ${ }^{1}$, Valentyna KOLODIY², Lyudmyla LYUBINSKA² \\ ${ }^{1}$ Institute of Ecology of the Carpathians, National Academy of Sciences of Ukraine \\ 4 Kozelnytska Str., Lviv 79026, Ukraine \\ kagalo@mail.lviv.ua \\ ${ }^{2}$ Ivan Ohienko Kamianets-Podilskyi National University \\ 61 Ohienko Str., Kamianets-Podilskyi, Khmelnytskyi Region 32301, Ukraine \\ kolodiyva@ukr.net \\ kvitkolub@gmail.com
}

\begin{abstract}
Kagalo A., Kolodiy V., Lyubinska L. Protection status assessment, prospects and methods of conservation of species of Schivereckia (Draba s. I.; Brassicaceae) in Ukraine. Ukr. Bot. J., 2018, 75(2): 169-178.

Abstract. On the basis of generalization of long-term research data on the status of populations and habitats of taxa of Schivereckia Andrz. ex Besser (Draba L. s. 1.; Brassicaceae), S. podolica and S. mutabilis (= S. podolica s. 1.) in Ukraine, the assessment of their conservation status and state and the recommended optimal modes for their conservation are provided. It has been shown that populations of these taxa are negatively affected by both anthropogenic and natural factors. Anthropogenic factors include pollution by household waste, sewage drains, grazing, trampling, burning, explosive works, mechanical destruction of ecotopes through the extraction of limestone or gravel. Natural factors are cenotic (reduction of competitiveness), biological (declining vitality of populations), physical (water erosion and natural degradation of slopes due to weathering of rocks), and climatic (influence of wind) ones. It is shown that, despite the fact that species of this genus are not directly harvested or destroyed by humans, their populations are indirectly influenced by negative anthropogenic and natural factors listed above. This negatively affects the vitality and viability of its local populations and cenopopulations. In this regard, it is expedient to transfer this species from the category Not Evaluated (currently applied in the Red Data Book of Ukraine) to the category Vulnerable. For further optimization of preservation of this species complex in various localities and habitats, it is advisable to develop appropriate nature conservation management plans, for Podilski Tovtry NNP as an example. Within the framework of such management plans it is advisable to take into account both scientific and administrative actions for species protection, as well as impact of environmental education and possibility of cultivation.
\end{abstract}

Keywords: conservation status, population state, anthropogenic factors, natural factors, Schivereckia podolica, Schivereckia mutabilis, protection

Conservation of relict and endemic species is among the most important tasks of biodiversity conservation, since, apart from their individual biotic uniqueness, such species perform important ecological functions as centres of unique consortia which are the basis of the existence of a number of other associated organisms (insects, fungi, etc.) (Stoiko, 1992; Stoiko et al., 1997, 2004; Holubets, 2003).

Concurrently, the contribution of novel habitats to supporting overall biodiversity in modern ecosystems may threat the populations of relict species. This is often manifested in the so-called phenomenon of "displacement of relicts" (Didukh, 1982, 1988). Due to this ecological effect, cenopopulations of relict species are mostly restricted to habitat types of cenotically open

(c) A. KAGALO, V. KOLODIY, L. LYUBINSKA, 2018 communities, where, in turn, ecotope conditions do not always adequately meet their ecological requirements.

Under such conditions, even species that are not directly threatened by human-induced factors or activities may become subject to various other factors and impacts resulting in inhibition of basic biological functions in populations; or species distribution is hampered by extreme factors to borders of species' ecological niche.

The genus Schivereckia Andrz. ex Besser (Alekseenko, 1946; Kolodiy, 2012; Mosyakin, 2016) could be considered as an example of endangered relict species in Ukraine. Two species are usually recognized in Ukraine: S. podolica (Besser) Andrz. ex DC. (Draba podolica (Besser) Regel) and S. mutabilis (M. Alexeenko) M. Alexeenko (Alekseenko, 1946); the second one is 
sometimes considered a synonym (Korotchenko et al., 2009).

It should be noted that systematics and nomenclature of this genus are controversial due to the latest molecular phylogenetic studies and nomenclatural analyses (for example, Mosyakin, 2015; German, 2017; etc.). But, since this publication is devoted to the issue of conservation of the undoubtedly rare representative (or representatives) of the genus, we consider it inappropriate to dwell on these issues.

However, since the boundaries between species are often unclear and are difficult to distinguish, in this article taxa are aggregated under the name Schivereckia podolica (Besser) Andrz. ex DC. s. 1. (incl. S. mutabilis (M. Alexeenko) M. Alexeenko; S. monticola M. Alexeenko subsp. mutabilis M. Alexeenko). It was included with the status Not Evaluated in the Red Data Book of Ukraine (Korotchenko et al., 2009) and in a number of international lists: the IUCN Red List, the European Red List, Annex II of the Bern Convention, Annex II of the European Union Council Directive on the conservation of natural habitats and of wild fauna and flora, a number of Red Data Books of administrative units of the Russian Federation, and other environmental documents (Mosyakin, 1999; Habitat concept..., 2012).

The reason for this approach is the comment of the cited author (Mosyakin, 2015, p. 1328) that: "Schivereckia podolica is listed in the IUCN Red List of Threatened Species, the European Red List, all editions of the Red Data Book of Ukraine, and the Red Book of Moldova. The Red Data Books of Ukraine and Moldova are legally binding documents under the special laws of these countries, which prescribe special procedures for making changes in the lists of protected species; thus, unnecessary nomenclatural changes are not desirable for conservational reasons. Schivereckia podolica was also protected in the former U.S.S.R. and now the species is included in red lists of ten administrative regions of Russia (http://oopt.aari.ru/bio/44366; accessed 4 Sep 2015)."

\section{Materials and methods}

Schivereckia podolica s. 1. is a chamaephyte, heliophyte, xeromesophyte, calciphilous, caudex polycarpic (Ekoflora..., 2007), southeast-European-northernBalkan subendemic with a disjunctive range; according to some researchers, it is a Tertiary relict (Alekseenko, 1946; Zaverukha, 1985).
General distribution of the species is in Central and Eastern Europe (Romania, Ukraine, Russia); and in the territory of Ukraine - in Western and Eastern Forest-Steppe (Ternopil, Khmelnytskyi, Chernivtsi regions), and Steppe (Odessa, Kharkiv, Donetsk, and Luhansk regions). In the Kharkiv, Donetsk and Luhansk administrative regions the species is known as $S$. mutabilis (Korotchenko et al., 2009; Lyubinska, 2003; Lyubinska, Kolodiy, 2017). The taxonomic status of the population in Odessa Region is not clear yet.

In Khmelnytskyi Region the species occurs in Horodok, Chemerivtsi and Kamianets-Podilskyi districts; in Ternopil Region: in Husiatyn and Zalishchyky districts; in Chernivtsi Region: in Kelmentsi and Sokyriany districts; in Donetsk Region: in Artemivsk District; in Kharkiv and Luhansk regions there is no up-to-date evidence of the current existence of its populations.

Materials of previous studies by various authors (Chopik, 1978; Zaverukha et al., 1983; Tkachenko, Dubovyk, 1986; Stoiko et al., 1997; Butylo, Bosak, 1998; Stoiko et al., 2004; Kovalchuk, 2008), as well as the results of our long-term studies of this species in various parts of its range (Lyubinska, 2000, 2003; Kovtun, Lyubinska, 2001; Kagalo, Skibitska, 2002, 2003; Kagalo et al., 2004, 2008; Kolodiy, 2005, 2006, 2007, 2008, 2011a, b, 2012, 2016a, b, c, 2017; Kolodiy et al., 2011; Kagalo, Kolodiy, 2011a, b, 2013; Kolodiy, Kagalo, 2008, 2010, 2011, 2014; Lyubinska, Kolodiy, 2017) were used to assess the protection status and the state of populations of the species.

All known localities of the species in Ukraine have been covered by special population studies: the local populations in the territory of Kamianets-Podilskyi, Chemerivtsi and Horodok districts of Khmelnytskyi Region (see below); the local population on Hostra Skelia Mt. near Vikno village, Husiatyn District of Ternopil Region; the local population on the slopes of the Dniester River near Hrushivtsi village, Kelmentsi District of Chernivtsi Region; the local population on the slopes of the Khadzhibei estuary between Yehorivka and Khomynka villages, Rozdilna District of Odessa Region; and the local population on the slopes of Maryina Hora (craggy bank of the Siverskyi Donets River) near Serebrianka village, Artemivsk District of Donetsk Region.

The integral studies of structural and functional parameters of local populations by standardized research methodology for endangered species have been conducted at all localities (Zlobin, 2009; Panchenko, 2011; Kagalo et al., 2012). 
The autphytosozological index was calculated and the phytosozological category (protection status) was determined (Stoiko et al., 2004).

In addition, the anthropogenic impact and negative impact of natural factors on the species were identified for each model site after processing of phytosociological relevés (Kagalo, Skibitska, 2003).

The main principles of strategies for species populations management in all known localities were developed based on research results.

\section{Results and discussion}

On the basis of the structural and functional parameters of local populations and cenopopulations for species of the genus, the autphytosozological index (API) was calculated. Accordingly, S. podolica s. 1. (including $S$. mutabilis) belongs to the fifth class of phytosozological indices (API $=12.1$ ). By the rating of API, S. podolica is on the 41-st place among more than 300 rare species of western regions of Ukraine (Stoiko et al., 2004). This species can be included in the fourth phytosozological category (PSC) (Stoiko et al., 2004), since its populations have limited distribution, its seed productivity and natural renewal are unsatisfactory, and its "cenotic stability" is low and the species is in a critical, threatened condition. At the same time, its populations (cenopopulations) are influenced only by indirect negative impact of anthropogenic and natural factors.

It should be noted that the largest enclave of species distribution within the territory of Ukraine is located in the Forest-Steppe zone - within the Ternopil, Khmelnytskyi and Chernivtsi regions of Ukraine; and the largest number of local populations is concentrated in the Transnistrian geographical region within the Podilski Tovtry National Nature Park (NNP). Therefore, model studies were carried out on the example of these objects, the results of which were subsequently verified on objects in the Odessa and Donetsk regions.

According to the results of our analysis of the mentioned references, as well as the results of our original research, the main anthropogenic factors (Table 1) that have negative influence on the state of species populations and their structural and functional parameters (Kolodiy, Kagalo, 2014) were determined, as well as information on the influence of natural factors (Table 2).

As to reducing of populations size, the natural factors that cause it also occur in other regions of Ukraine, although their influence is less apparent; in particular,
Table 1. Anthropogenic factors of Schivereckia podolica s. I. population decline in the territory of Podilski Tovtry NNP

\begin{tabular}{|l|c|c|c|c|c|c|}
\hline \multirow{2}{*}{\multicolumn{1}{|c|}{ Factors }} & \multicolumn{7}{|c|}{ Territory name } \\
\cline { 2 - 8 } & BG & KS & UBR & SC & KGQ & VT \\
\hline $\begin{array}{l}\text { Ecotopes polluted by } \\
\text { household waste }\end{array}$ & + & + & + & + & - & - \\
\hline Pollution by sewage drains & - & - & - & + & - & - \\
\hline Grazing & - & - & - & + & - & - \\
\hline Trampling & + & + & + & + & - & - \\
\hline Burning & + & - & - & + & - & + \\
\hline Explosive works & - & - & - & - & + & - \\
\hline $\begin{array}{l}\text { Mechanical destruction } \\
\text { of ecotopes (extraction of } \\
\text { limestone, rubble) }\end{array}$ & - & - & - & - & - & + \\
\hline
\end{tabular}

Here and in Table 2: BG - Bakotska Gulf, KS - Kytaihorodska Stinka; UBR - Ustianskyi Botanical Reserve; SC - Smotrych Canyon (within the city of Kamianets-Podilskyi); KGQ - Kudrinetskyi gypsum quarry; VT - Vilkhovetski Tovtry).

Table 2. Natural factors of Schivereckia podolica s. l. population decline in the territory of Podilski Tovtry NNP

\begin{tabular}{|l|c|c|c|c|c|c|}
\hline \multirow{2}{*}{ Factors } & \multicolumn{7}{|c|}{ Territory name } \\
\cline { 2 - 7 } & BG & KS & UBR & SC & KGQ & VT \\
\hline $\begin{array}{l}\text { Cenotic (reduction of } \\
\text { competitiveness) }\end{array}$ & + & + & + & + & + & + \\
\hline $\begin{array}{l}\text { Biological (reducing the vitality } \\
\text { of the population) }\end{array}$ & + & + & + & + & + & - \\
\hline $\begin{array}{l}\text { Physical (water erosion and } \\
\text { natural degradation of the slopes } \\
\text { through the weathering of rocks) }\end{array}$ & - & + & + & + & + & - \\
\hline Climatic (wind effect) & + & + & + & + & + & + \\
\hline
\end{tabular}

habitats of the Transnistrian region are characterized by a number of geomorphological features that increase the effect of these factors. In particular, it is the presence of very steep slopes of the canyon-like valley of the Dniester River and its tributaries, which causes the increase of natural linear and plane water erosion, as well as the increase of wind influence on plants and on dispersal of its seeds.

The territory over Bakotska Gulf (slopes above the Dniester water reservoir) between Kolodiivka, Kashtanivka and Horaivka villages, KamianetsPodilskyi District) almost each year is affected by grass burning that occurs at the beginning of the vegetation season. In addition, the local population of this area is tramped because it is located near the Bakotskyi Cliff Monastery, which is regularly visited by numerous tourists. 
The mentioned factors caused the suppressing of S. podolica population - through reducing the number of individuals, which led to a decrease in seed productivity every year. The situation was not substantially affected by the installation of fences by the employees of the Podilski Tovtry National Nature Park, which clearly separated the territory for excursions from the protected zone.

In the territory of the Ustianskyi Botanical Reserve on the wall of the bank of the Smotrych River near Ustia village, Kamianets-Podilskyi District, Khmelnytskyi Region, S. podolica grows on the steep slopes of the southern and southwest exposition. Comparing the results published in previous years (Butylo, Bosak, 1998; Kolodiy, Kagalo, 2014) and our continued research, one can conclude that the population size reduced. Moreover, the reason lies in the influence of both kinds of factors, anthropogenic and natural ones.

Also, the destruction of ecotopes continues under the influence of water erosion as a result of the crumbling of limestone-crushed "shelves", on which the species grows. It is unfavorable too that the $S$. podolica population grows in the vicinity of the paths leading from the road to the Smotrych River, so the species undergoes a significant anthropogenic impact (clogging, trampling). However, this area is not affected by burning, because the plant community belongs to typical rock formations with a minimum participation of grass, so the tussock is almost not formed. It has also positive effect that the Smotrych River slopes have in certain areas a declivity from $45^{\circ}$ to $90^{\circ}$, which makes it difficult to graze on or to use this territory for recreational purposes.

The special microclimate and the presence of original geomorphological formations (outcrops, depressions, walls, etc.) on the territory of the Geological Nature Monument "Smotrytskyi Canyon" also contribute to the distribution of $S$. podolica within the limits of Kamianets-Podilskyi city, including Tsybulivka vilage, Kamianets-Podilskyi District (Kagalo, Skibitska, 2003).

In the territory of the Smotrych Canyon (within Kamianets-Podilskyi city) the species grows on the slopes of the northern, north-western and northeastern expositions. Due to the large area of distribution and heterogeneous settlement compared to other local populations, $S$. podolica in this territory is most affected by anthropogenic and natural factors, comparing to its other populations.

A special locality of $S$. podolica is found on the bank of the Zbruch River near Kudrynetskyi gypsum quarry near Kudryntsi village, Kamianets-Podilskyi District. Here the species is influenced by factors similar to those in the territory of the Ustianskyi Botanical Reserve. The only exception is that this area is almost inaccessible to humans and farm animals due to its location (steep bank, up to $90^{\circ}$ at certain areas). Due to the features of the substrate, the landslides also occur under the influence of thawed waters. This territory, like other areas on the steep slopes (Table 1), is influenced by wind that promotes the "blowout" of the substrate on which the individuals of $S$. podolica grow, which leads to their drying, as well as causes its very small seeds to be blown to places unsuitable for their germination.

Of particular interest is a normal prosperous population of Schivereckia podolica with the full age spectrum growing with a complex of contiguous rare species in communities of the abandoned quarry near the Vilkhivtsi village, Chemerivtsi District, Khmelnytskyi Region. In this case, the territory is characterized as the secondary ecotope for the formation of stable populations with full age spectrum (Kagalo et al., 2008; Kolodiy, Kagalo, 2014), where it exists in the anthropogenic type of habitat, which is an analogue of the natural habitat (Kagalo, Kolodiy, 2013). This locality, in addition, is situated at a considerable distance from the settlements, which contributes to better conditions of the population. During the observations, there were no cases of anthropogenic influences for several years. Mainly, here $S$. podolica is under the influence of wind and high temperatures, as it grows on the top of the hills. The certain role in it also plays the absence of trees on this territory (except some isolated shrubs) that, due to their morphological characteristics, are not capable of preventing insolation and of reducing wind power. As for the herb layer, it is dominated by mosses that are capable of retaining moisture but do not protect from wind.

In the territory of Odessa Region, the species grows on the shell limestone deposits of the south-western coast of the upper part of the Khadzhibei estuary. The local population is distributed on the top of the slope with the vertical or strongly sloping boulders of the carbonate shell rock, with eastern and north-eastern exposition, and moderately shaded. The locality is largely anthropogenically transformed; part of the outcrop has a secondary origin, since it was formed as a result of extraction of shell limestone.

Some remoteness from settlements and relatively difficult accessibility of the population locality 
contributes to maintaining its satisfactory condition. Only some traces of the territory's clogging and recreational pollutions (remains of fireplaces) are observed. The area is almost not affected by grazing, since the population is concentrated on steep cliffs, which are inaccessible to livestock; grazing occurs only in the lower part of the slope. The main factors influencing the population state are natural; in particular, these are wind and temperature.

In Donetsk Region, $S$. mutabilis grows; its difference from $S$. podolica is negligible and consists of some minor morphological features (Alekseenko, 1946).

At present, only one locality of this species is known to be found - so called Maryina Hora, near Serebrianka village, Artemivsk Region, on the slopes of the northern exposition.

According to the results of previous studies (Tkachenko, Dubovyk, 1986; Burda et al., 1991), it was established that the main negative factor influencing the population is grazing, the result of which is the destruction of vegetation of the northern slope of Maryina Hora. This leads to the appearance of chalk openings, landslides, small ravines, paths, etc.

However, according to research results of 2006 and 2008, it was noted (Kolodiy, 2006; Kolodiy, Kagalo, 2014) that the state of the population has improved significantly as compared with the second half of the last century. Obviously, this was facilitated by granting the territory the protected status. On the other hand, the direct man-made impact increased somewhat: the remains of fire, rubbish, footpaths (the Siverskyi Donets River is located at the foot of the mountain, to which the tourists descend), but it did not significantly affect the condition of the local population. Positive effect has the presence of a fence on the south side of the slope from Serebrianka village, which prevents the movement of transport to the mountain; that it reduces the traffic pressure, could lead to crumbling of the substrate.

According to the results of structural and populational studies in this locality, it can be established that the population is affected by the same natural factors as in other localities of the species, which should be taken into account when conducting nature conservation management of the territory. The population of the species in this territory is yearly monitored by employees of the Donetsk Botanical Garden of the National Academy of Sciences of Ukraine, who are also engaged in its introduction and cultivation.
However, in the autumn of 2015 the territory of the reserve tract Maryina Hora was completely burnt down. Although the plant cover was restored intensively in July 2016 , it is now difficult to give unambiguous estimates of the state of the population of $S$. mutabilis.

\section{Conclusions}

On the basis of the research, it has been found that, despite the fact that species of the genus Schivereckia are not directly threatened with destruction, they are under significant threat, which is due to the peculiarities of their relict status. In particular, it is an indirect negative influence of anthropogenic and natural factors that affects the vitality and viability of its local populations and coenopopulations.

In this regard, it is advisable to transfer $S$. podolica s. 1. from the category Not Evaluated (Lyubinska, 2003) to the category Vulnerable.

For further optimization of the species preservation in its various localities and habitats, it is advisable to develop appropriate nature protection management plans by the example of Podilski Tovtry NNP (Lyubinska, 2000, 2003). Within such management plans it is expedient to take into account the following activities:

- To continue studying the state and dynamics of $S$. podolica and $S$. mutabilis populations in order to establish optimal conditions for their normal viability;

- Restrict the unregulated recreation by establishing information banners; the territories not covered yet by the state protection should be included in the existing protected areas, or it is expedient to create appropriate nature protection units for it;

- To improve environmental awareness of guides, at educational establishments and representatives of institutions responsible for areas of distribution of these species;

- To involve media to information sharing on the uniqueness and status of $S$. podolica and $S$. mutabilis;

- To strengthen the control over adherence to the prohibition of activities that lead to reduction in the number of species (all the above considered localities of $S$. podolica are located in Podilski Tovtry NNP, and these of $S$. mutabilis, in the protected tract ("urochyshche");

- To involve botanical gardens, ecological and naturalistic centres and other institutions prior to the introduction of species for its conservation and detailed study ex situ. 


\section{REFERENCES}

Alekseenko M.I. In: Notulae Systematicae ex Herbario Instituti Botanici nomine V.L. Komarovii Academiae Scientiarum URSS. Moscow; Leningrad, 1946, vol. 9 (4-12), pp. 215-231. [Алексеенко М.И. Новые виды рода Schivereckia Andrz. В кн.: Ботанические материалы гербария Ботанического института им. В.Л. Комарова АН СССР. Под ред. В.Л. Комарова. М.; Л., 1946, т. 9, вып. 4-12, с. 215-231].

Burda R.I., Kharkhota A.I., Ostapko V.M. Plants protection of Artemovsk District, Donetsk Region, included in the Red Data Book of Ukraine, and determination of the resources of medicinal plants in the region (report of 1991). Donetsk, 1991, pp. 63-64; pp. 292-294, manuscript. [Бурда Р.И., Хархота А.И., Остапко В.М. Охрана растений $A p$ темовского района Донецкой области, занесенных в Красную книгу Украины и определение ресурсов лекарственных растений в районе (отчет за 1991 г.). Донецк, 1991, с. 63-64; с. 292-294, рукопись].

Butylo M.D., Bosak M.L. In: The role of protected natural areas in diversity conservation: mat. of sci. conf. devoted to the 75th anniv. of Kaniv Nature Reserve. Kaniv, 1998, pp. 57-58. [Бутило М.Д., Босак М.Л. Поширення і еколого-ценотичні особливості деяких рідкісних видів рослин на Поділлі. В зб.: Роль охоронюваних природних територій у збереженні різноманіття: мат. наук. конф., присвяч. 75-річчю Канівського природного заповідника (Канів, 8-10 вересня 1998 р). Канів, 1998, c. 57-58].

Chopik V.I. Rare and endangered plants in Ukraine: a reference manual. Kiev: Naukova Dumka, 1978, pp. 171-172. [Чопик В.И. Редкие и исчезающие растения Украины: Справочник. Киев: Наук. думка, 1978, с. 171-172].

German D.A. Proposal to conserve the name Alyssum hyperboreum (Draba hyperborea) with a conserved type (Cruciferae). Taxon, 2017, 66(3): 755-756.

Holubets M.A. Biotic diversity and scientific approaches to its conservation. Lviv: Liga-Press, 2003, 33 pр. [Голубець М.А. Біотична різноманітність і наукові підходи до ї̈ збереження. Львів: Ліга-Прес, 2003, 33 с.].

Didukh Ya.P. Bot. Zhurn., 1982, 67(7): 925-935. [Дидух Я.П. Проблемы активности видов растений. Бот. журн., 1982, 67(7): 925-935].

Didukh Ya.P. Bot. Zhurn., 1988, 73(12): 1686-1698. [Дидух Я.П. Эколого-ценотические особенности поведения некоторых реликтовых и редких видов в свете теорий оттеснения реликтов. Бот. журн., 1988, 73(12): 1686-1698].

Habitat concept of biodiversity conservation: basic documents of the European Union. Eds A.A. Kagalo, B.H. Prots. Lviv: ZUKC, 2012, 278 pp. [Кагало О.О., Проць Б.Г. (ред.) Оселищна концепція збереження біорізноманіття: базові документи Європейського Союзу. Львів: ЗУКЦ, 2012, 278 с.].

Ilinska A.P., Didukh Ya.P., Burda R.I., Korotchenko I.A. Ecoflora of Ukraine. Ed. Ya.P. Didukh. Kyiv: Phytosociocenter, 2007, vol. 5, 584 рр. [Ільїнська А.П., Дідух Я.П., Бурда Р.І., Коротченко І.А. Екофлора України. Відпов. ред. Я.П. Дідух. Київ: Фітосоціоцентр, 2007, т. 5, 584 с.].
Kagalo A.A., Kolodiy V.A. In: Falz-Fein Readings: Coll. of sci. works. Kherson: PP Vishemyrskyi, 2011a, pp. 52-53. [Кагало О.О., Колодій В.А. Мінливість структурно-функціональних параметрів ценопопуляцій Schivereckia podolica Andrz. ex DC. (Brassicaceae) в умовах Смотрицького каньйону (м. Кам'янець-Подільський, Хмельницька область). В зб. Фальцфейнівські читання: Зб. наук. праць. Херсон: ПП Вишемирський, 2011a, с. 52-53].

Kagalo A.A., Kolodiy V.A. Podilskyi Natural Herald, 2011b, 2: 140-151. [Кагало О.О., Колодій В.А. Стан, структура та морфологічні особливості популяції Schivereckia podolica (Besser) Andrz. ex DC. (Brassicaceae) в умовах Смотрицького каньйону (м. Кам'янецьПодільський, Хмельницька область). Поділ. природ. вісник, 2011b, 2: 140-151].

Kagalo A.A., Kolodiy V.A. Biological Systems, 2013, 5(1): 39-42. [Кагало О.О., Колодій В.А. Особливості й перспективи реалізації оселищних підходів до збереження природних популяцій раритетних видів (на прикладі Schivereckia podolica (Bess.) Andrz. ex DC.). Біол. системи, 2013, 5(1): 39-42].

Kagalo A.A., Skibitska N.V., Bednarska I.O. In: Protection and management of objects of non-living nature in protected areas: mat. of intern. sci.-pract. conf. HrymailivTernopil: Dzhura, 2008, pp. 110-115. [Кагало O.O., Скібіцька Н.В., Беднарська I.О, Андрєєва О.О., Колодій В.А. Антропогенні відслонення корінних порід як об'єкт охорони для збереження біорізноманіття. В зб.: Охорона і менеджмент об'єктів неживої природи на заповідних територіях: мат. міжнар. наук.-практ. конф. (смт Гримайлів, 21-23 травня 2008 р.). Гримайлів-Тернопіль: Джура, 2008, с. 110-115].

Kagalo A.A., Skibitska N.V., Lyubinska L.H. In: Vascular plants of Kamianets-Podilskyi city. In: Biodiversity of Kamianets-Podilskyi. Eds A.A. Kagalo, M.V. Shevera, A.A. Levanets. Lviv: Liga-Press, 2004, pp. 82-134. [Кагало О.О., Скібіцька Н.В., Любінська Л.Г., Гузік Я., Протопопова В.В., Шевера М.В. Судинні рослини м. Кам'янець-Подільський. В кн.: Біорізноманіття Кам'яния-Подільського. Ред. О.О. Кагало, М.В. Шевера, А.А. Леванець. Львів: Ліга-Прес, 2004, c. 82-134].

Kagalo A., Skibitska N. Visnyk Lviv. Univ. Ser. Biology, 2002, 31: 55-65. [Кагало О., Скібіцька Н. Флоросозологічна оцінка каньйону р. Смотрич як частини заповідного ядра національного природного парку "Подільські Товтри". Вісн. Львів. ун-mу. Сер. біологічна, 2002, 31: 55-65].

Kagalo A.A., Skibitska N.V. In: The role of protected areas of Western Podillia and Jura of Ojców in preservation of biological and landscape diversity: Coll. of sci. works. Hrymailiv; Ternopil: Lyleya, 2003, pp. 277-283. [Kaгало О.О., Скібіцька Н.В. Флористична репрезентативність геологічної пам'ятки природи "Смотрицький каньйон" (НПП "Подільські Товтри"). В кн.: Роль природно-заповідних територій Західного Поділля та Юри Ойцовської у збереженні біологічного та ландшафтного різноманіття: зб. наук. праць. Гримайлів; Тернопіль: Лілея, 2003, с. 277-283]. 
Kagalo A.A., Tsaryk Y.V., Skibitska N.V., Danylyk I.M., Sychak N.M., Bednarska I.O., Doroshenko K.V. Proposals to the monitoring method of populations of plant species included in the Red Data Book of Ukraine. Bull. Precarpathian Nats. Univ. Ser. Biology, 2012, 17: 3-8. [Кагало О.О., Царик Й.В., Скібіцька Н.В., Данилик I.М., Сичак Н.М., Беднарська I.О., Дорошенко К.В. Пропозиції до методики моніторингу популяцій видів рослин, включених до Червоної книги України. Вісн. Прикарпат. наи. ун-ту. Сер. Біологія, 2012, 17: 3-8].

Kolodiy V., Kagalo A., Bondarenko O. State of the local population of Schivereckia podolica Andrz. ex DC. in the conditions of Odessa region. In: Biodiversity. Ecology. Adaptation. Evolution: mat. of the 5th Intern. conf. of young scientists dedicated to the $160^{\text {th }}$ anniv. of Professor F.M. Kamenskyi (Odessa, June 13-17, 2011). Odessa: Print. House, 2011, pp. 28-29.

Kolodiy V.A., Kagalo A.A. In: Materials of the XIII Congress of the Ukrainian Botanical Society. Lviv, 2011, p. 55. [Колодій В.А., Кагало О.О. Географічне поширення Schivereckia podolica в Україні. В кН.: Матеріали ХІІІ з'їзу Українського ботанічного товариства (19-23 вересня 2011 р., м. Львів). Львів, 2011, с. 55].

Kolodiy V.A., Kagalo A.A. In: The Plant Kingdom in the Red Data Book of Ukraine: Implementing the Global Strategy for Plant Conservation: proc. of III Intern. conf. Lviv: Prostir-M Ltd., 2014, pp. 122-125. [Колодій В.А., Кагало О.О. Созологічна оцінка та перспективи збереження роду Schivereckia Andrz. в Україні. В кн.: Рослинний світ у Червоній книзі України: впровадження Глобальної стратегії збереження рослин: мат. III Міжннар. наук. конф. (4-7червня 2014 р., Львів). Львів: ТзОВ Простір-М, 2014, с. 122-125].

Kolodiy V.A., Kagalo A.A. Schivereckia podolica (Bess.) Andrz. ex DC. in the condition of anthropogenic stress. In: Anthropization and Environment of Rural Settlements. Flora and Vegetation. Kamyanets-Podilskiy \& Boyany: mat. IX Intern. conf. (Ukraine, 29 June-01 July 2010). Kyiv, 2010, p. 36.

Kolodiy V.A., Kagalo A.A In: The significance and perspectives of stationary research for biodiversity conservation:mat. of the intern. sci. conf., devoted to the 50h anniv. of the functioning of the high-altitude biological field station Pozhyzhevska. Lviv, 2008, pp. 199-200. [Колодій В.А., Кагало О.О. Еколого-ценотині особливості видів роду Schivereckia Andrz. (Brassicaceae) в Україні. В кн.: Значення та перспективи стаціонарних досліджень для збереження біорізноманіття: мат. міжнар. наук. конф., присвяч. 50-річчю функціонування високогірного біологічного стаціонару "Пожижевська" (Львів-Пожижевська, 23-27 вересня 2008 р). Львів, 2008, c. 199-200].

Kolodiy V.A., Kagalo A.A., Valchuk M.V. In: Environmental protection and the problems of sustainable use of nature: mat. of Intern. conf., dedicated to the $15^{\text {th }}$ anniv. of the functioning of Podilski Tovtry NNP. Kamianets-Podilskyi: Moshynskyi, 2011, pp. 60-62. [Кагало O.O., Колодій В.А., Вальчук М.В. Поширення Schivereckia podolica Andrz. ex. DC. на території НПП "Поділь- ські Товтри" В кн.: Охорона довкілля та проблеми збалансованого природокористування: мат. міжнар. конф., присвяч. 15-річчю функціонування НПП "Подільські Товтри" (10-11 травня 2011 р., Кам'янецьПодільський). Кам'янець-Подільський: Мошинський, 2011, с. 60-62].

Kolodiy V.A. In: Scientific works of Kamianets-Podilskyi State University: digest on the basis of the sci. conf. report of teachers and post-graduate students. Kamianets-Podilskyi: Kamianets-Podilskyi State Univ., 2005, vol. 4, issue 3, pp. 77-78. [Колодій В.А. Особливості морфології насіння та насінна продуктивність у квіткових рослин. В кн.: Наукові праці Кам'янець-Подільського державного університету: зб. за підсумками звітної наук. конф. викладачів $і$ аспірантів. Кам'янецьПодільський: Кам'янець-Подільський держ. ун-т, 2005, т. 4, вип. 3, с. 77-78].

Kolodiy V.A. In: Scientific works of the Kamianets-Podilskyi State University: digest on the basis of the sci. conf. report of teachers and post-graduate students. Kamianets-Podilskyi: Kamianets-Podilskyi State Univ., 2006, vol. 5, issue 2, pp. 181-182. [Колодій В.А. Особливості Schivereckia mutabilis (M. Alexeenko) в умовах Артемівського району Донецької області. В кн.: Наукові праці Кам'янець-Подільського державного університету: зб. за підсумками звітної наук. конф. викладачів ma аспірантів. Кам'янець-Подільський: Кам'янецьПодільськ. держ. ун-т, 2006, т. 5, вип. 2, с. 181-182].

Kolodiy V.A. In: Scientific Principles of Biodiversity Conservation: mat. of the Eighth sci. conf. of young scientists. Lviv, 2007, pp. 52-55. [Колодій В.А. Поширення видів роду Schivereckia Andrz. в Україні. В кн.: Наукові основи збереження біотичної різноманітності: мат. Восьмої наук. конф. молод. учених (Львів, 5-6 листопада 2007 р.). Львів, 2007, с. 52-55].

Kolodiy V.A. In: Advances in botany and ecology: mat. of the intern. conf. of young scientists. Kiev, 2008, pp. 159-162. [Колодій В.A. Schivereckia podolica Andrz. ex DC. s. 1. в умовах Смотрицького каньйону (Кам'янецьке Придністров'я). В кн.: Актуальні проблеми ботаніки та екології: мат. міжнар. конф. молод. учених (13-16 серпня 2008 р., м. Кам'янець-Подільський). Київ, 2008, c. 159-162].

Kolodiy V.A. In: Advances in botany and ecology: mat. of the intern. conf. of young scientists. Kyiv: Lazuryt-Poligraph, 2011a, pp. 109-110. [Колодій В.А. Вікова структура ценопопуляцій Schivereckia podolica Andrz. ex DC. s. 1 в умовах Смотрицького каньйону (Кам'янецьПодільський р-н, Хмельницька обл.). В кн.: Актуальні проблеми ботаніки та екології: мат. міжнар. конф. молод. учених (9-13 серпня 2011 р., м. Березне, Рівненська обл., Україна). Київ: ТОВ Лазурит-Поліграф, 2011a, с. 109-110].

Kolodiy V.A. In: Fundamental and applied research in biology: mat. of the $2^{\text {nd }}$ Intern. sci. conf. of students, postgraduates and young scientists. Donetsk: Noulidzh Publ., 2011b, pp. 147-148. [Колодій В.А. Schivereckia podolica (Bess.) Andrz. ex DC. в умовах антропогенного навантаження у межах Хмельницької області. В зб.: Фундаментальні та прикладні дослідження в біології: мат. 2-ої 
Міжнар. наук. конф. студентів, аспірантів та молодих учених. Донецьк: Ноулідж, 2011b, с. 147-148].

Kolodiy V.A. In: Scientific principles of biodiversity conservation: mat. of the Eleventh sci. conf. of young scientists. Lviv, 2012, pp. 68-69. [Колодій В.А. Рід Schivereckia Andrz. в Україні: номенклатурна історія таксонів. В зб.: Наукові основи збереження біотичної різноманітності: мат. Одинадиятої наук. конф. молод. учених (Львів, 24-25 травня 2012 р.). Львів, 2012, с. 68-69].

Kolodiy V.A. In: Scientific and practical conference: Dynamics of biological and landscape diversity of protected areas. Kamianets-Podilskyi: Ruta, 2016a, pp. 66-68. [Колодій В.А. Стан популяції Schivereckia podolica (Besser) Andrz. ex DC. в умовах геологічної пам'ятки природи "Китайогордське відслонення" (Кам'янецьПодільський р-н, Хмельницька обл.). В зб.: Науково-практична конференція "Динаміка біологічного та ландшафтного різноманіття заповідних територій", (25-27 травня 2016 р., Кам'янець-Подільський). Кам'янець-Подільський: Рута, 2016а, с. 66-68].

Kolodiy V.A. In: Unique objects of nature and public sphere of Podillia; regional peculiarities of the integration of economic and social trends in their development as a condition for effective conservation: sci. works of the intern. sci. and pract. conf. Podilski Readings. Kamianets-Podilskyi: Ruta, 2016b, pp. 203-204. [Колодій B.А. Стан популяції Schivereckia podolica (Besser) Andrz. ex DC. в умовах заказника місцевого значення "Устянський" (Кам'янець-Подільський р-н, Хмельницька обл.). В зб.: Унікальні об'єкти природи і суспільної сфери Поділля; регіональні особливості інтеграції економічних $i$ соціальних напрямків їх розвитку як умова ефективного збереження: зб. наук. праць міжнар. наук.практ. конф. "Подільські читання" (м. Кам'янецьПодільський, 3-5 листопада 2016 р.). Кам'янецьПодільський: Рута, 2016b, с. 203-204].

Kolodiy V.A. Scientific works of the Kamianets-Podilskyi Nats. Univ., 2016c, 15(2): 6-7. [Колодій В.А. Стан, структура та морфологічні особливості популяції Schivereckia podolica (Besser) Andrz. ех DC. в умовах околиць с. Кудренці Кам'янець-Подільського району Хмельницької області. Наук. праці Кам'янецьПоділ. наи. ун-ту, 2016c, 15(2): 6-7].

Kolodiy V.A. In: International Scientific and Practical Conference: World Science. June 2017, 6(22), vol. 5, pp. 11-12. [Колодій В.А. Стан популяції Schivereckia podolica Andrz. в умовах околиць с. Вільхівці Чемеровецького району Хмельницької області, Україна). В зб.: International Scientific and Practical Conference "World Science" June 2017, 6(22), vol.5, c. 11-12].

Kolodiy V.A. In: Advances in botany and ecology: mat. of the intern. conf. of young scientists. Uzhgorod: Publ. House FOP Breza A.E., 2012, pp. 89-90. [Колодій В.А. Поширення Schivereckia podolica (Besser) Andrz. ех DC. в умовах Чернівецької області. В зб.: Актуальні проблеми ботаніки та екології: мат. міжнар. конф. молод. учених (Ужгород, 19-23 вересня 2012 р.). Ужгород: Вид-во ФОП Бреза А.Е., 2012, с. 89-90].
Korotchenko I.A., Kagalo A.A., IIinska A.P., Chorney I.I. Schivereckia podolica. In: Red Data Book of Ukraine. Plant Kingdom. Ed. Ya.P. Didukh. Kyiv: Globalconsulting, 2009, p. 376. [Коротченко I.A., Кагало О.О., Ільїнська А.П., Чорней I.I. Шиверекія подільська - Schivereckia podolica (Besser) Andrz. ex DC. (incl. S. mutabilis (M. Alexeenko) M. Alexeenko). В кн.: Червона книга Украӥни. Рослинний світ. За ред. Я.П. Дідуха. Київ: Глобалконсалтинг, 2009, с. 376].

Kovalchuk S.I. In: Protection and management of objects of non-living nature in protected areas: mat. of the intern. sci. and pract. conf. (Hrymailiv village, May 21-23, 2008). Hrymailiv; Ternopil: Dzhura, 2008, pp. 140-146. [Ковальчук C.I. Товтрове пасмо Поділля: проблеми охорони і природокористування. В зб.: Охорона $i$ менеджмент об'єктів неживої природи на заповідних територіях: мат. міжнар. науко.-практ. конф. Гримайлів; Тернопіль: Джура, 2008, с. 140-146].

Kovtun I.V., Lyubinska L.G. Ukr. Bot. J., 2001, 58(1): 5963. [Ковтун І.В., Любінська Л.Г. Рідкісні види каньйону р. Смотрич в межах м. Кам'янця-Подільського. Укр. бот. журрн., 2001, 58(1): 59-63].

Lyubinska L.H. In: Chronicle of Podilski Tovtry NPP, 2000, 3: 114-116, manuscript. [Любінська Л.Г. Менеджмент-план Шиверекія подільська (Schivereckia podolica Andrz. ex DC.) НПП "Подільські Товтри". В зб.: Літопис НПП "Подільські Товтри", 2000, 3: 114-116, рукопис].

Lyubinska L.H. In: The state of the natural complexes of the Crimean Nature Reserve and other protected territories of Ukraine, their study and protection: mat. of the sci. and pract. conf. devoted to the $80^{\text {th }}$ anniv. of the Crimean Natural Reserve. Alushta, 2003, pp. 88-91 [Любінська Л.Г. Менеджмент популяцій рідкісних видів НПП "Подільські Товтри". В зб.: Состояние природных комплексов Крымского природного заповедника и других заповедных территорий Украины, их изучение и охрана: мат. науч.-практ. конф., посвящ. 80-летию Крымского природного заповедника. Алушта, 2003, с. 88-91].

Lyubinska L.H., Kolodiy V.A. Schivereckia podolica Andrz. ex DC. In: Vascular plants of the Emerald Network of Ukraine under the protection of the Bern Convention. Ed. V.A. Solomakha. Zhytomyr: O.O. Yevniuk Publ., 2017a, pp. 128-129. [Любінська Л.Г., Колодій В.А. Шиверекія подільська. В кн.: Судинні рослини Смарагдової мережі України під охороною Бернської конвенції. Ред. В.А. Соломаха. Житомир: Вид-во О.О. Євенюк, 2017а, с. 128-129].

Lyubinska L.H., Kolodiy V.A. Ustia-Shutnivtsi. In: Important Plant Areas of Ukraine. Ed. V.A. Onyshchenko. Kyiv: Alterpress, 2017b, pp. 323-324.

Mosyakin S.L. Ukr. Bot. J., 1999, 56(1): 79-88. [Мосякін С.Л. Рослини України у світовому Червоному списку. Укр. бот. журнн., 1999, 56(1): 79-88].

Mosyakin S.L. Proposal to reject the name Alyssum hyperboreum (Draba hyperborea, Schivereckia hyperborea) (Brassicaceae). Taxon, 2015, 64(6): 1326-1328.

Mosyakin S.L. In: Rare plants and fungi of Ukraine and adjacent territories: implementation of nature conservation 
strategies: mat. of the IV Intern. conf. Kyiv: Palyvoda A.V., 2016, pp. 105-107. [Мосякін С.Л. Нові назви для Schivereckia podolica та Syrenia talijevii (Brassicaceae): таксономічне і номенклатурне роз'яснення. В зб.: Рідкісні рослини і гриби України та прилеглих території: реалізація природоохоронних стратегій: мат. IV Міжнар. конф. (16-20 травня 2016 р., Київ, Україна). Київ: Паливода А.В., 2016, с. 105-107].

Panchenko S.M. Ukr. Bot. J., 2011, 68(5): 672-685. [Панченко C.M. Методи картування при вивчення екології популяцій рідкісних видів рослин. Укр. бот. журн., 2011, 68(5): 672-685].

Stoiko S.M. Ukr. Bot. J., 1992, 49(1): 72-77. [Стойко С.М. Созологічна категоризація та екологічні засади збереження рідкісних і зникаючих видів рослин. Укр. бот. журн., 1992, 49(1): 72-77].

Stoiko S.M., Milkina L.I., Yashchenko P.T. Rare phytocenoses of the western regions of Ukraine (Regional Green Book). Lviv: Polli, 1997, 190 pp. [Стойко C.M., Мілкіна Л.І., Ященко П.Т. Раритетні фітоценози західних регіонів України (Регіональна "Зелена книга"). Львів: Поллі, 1997, 190 с.].

Stoiko S.M., Yashchenko P.T., Kagalo A.A. Protected vascular plants of western regions of Ukraine (assessment and conservation). Lviv: Liga-Press, 2004, 232 pp. [Стойко С.М., Ященко П.Т., Кагало О.О. Раритетний фітогенофонд західних регіонів України (созологічна оцінка й наукові засади охорони). Львів: Ліга-Прес, 2004, 232 c.].

Tkachenko V.S., Dubovyk O.M. Ukr. Bot. J., 1986, 43(3): 89-93. [Ткаченко В.С., Дубовик О.М. Еколого-ценотичні особливості біотопів Schivereckia mutabilis (M. Alexeenko) M. Alexeenko в басейні Сіверського Дінця та необхідність їх охорони. Укр. бот. жмрн., 1986, 43(3): 89-93].

Zaverukha B.V. Flora of Volyno-Podolia and its genesis. Kiev: Naukova Dumka, 1985, 192 pp. [Заверуха Б.В. Флора Волыно-Подолии и ее генезис. Киев: Наук. думка, 1985, 192 c.].

Zaverukha B.V., Andrienko T.L., Protopopova V.V. Protected plants of Ukraine. Kiev: Naukova Dumka, 1983, 175 pp. [Заверуха Б.В., Андриенко Т.Л., Протопопова В.В. Охраняемые растения Украины. Киев: Наук. думка, 1983, 175 c.].

Zlobin Yu.A. Population ecology of plants: current state, growth points. Sumy: University Book, 2009, 263 pp. [Злобин Ю.А. Популяционная экология растений: современное состояние, точки роста: монография. Сумы: Университет. книга, 2009, 263 с.].

Recommended for publication

Received 23.10.2017 
Кагало O. ${ }^{1}$, Колодій В. ${ }^{2}$, Любінська Л. ${ }^{2}$ Созологічна оцінка та перспективи й методи збереження видів роду Schivereckia (Draba s. l.; Brassicaceae) в Україні. Укр. бот. журн., 2018, 75(2): 169-178.

${ }^{1}$ Інститут екології Карпат НАН України вул. Козельницька, 4, Львів 79026, Україна

${ }^{2}$ Кам'янець-Подільський національний університет імені Івана Огієнка

вул. Огієнка, 61, Кам'янець-Подільський 32301 , Хмельницька обл., Україна

На підставі узагальнення матеріалів багаторічних досліджень стану популяцій та оселищ видів роду Schivereckia (Brassicaceae) - Schivereckia podolica та S. mutabilis (= S. podolica s. 1.) в Україні дана оцінка їхнього стану й охоронного статусу та рекомендовані оптимальні шляхи збереження. Показано, що популяції виду зазнають негативного впливу як антропогенних (засмічення екотопів побутовим сміттям, заливання каналізаційними стоками, випасання, витоптування, випалювання, вибухові роботи, механічне руйнування екотопів внаслідок видобування вапняку, щебеню), так і природних (ценотичних (зменшення конкурентної здатності), біологічних (зменшення життєвості популяції), фізичних (водна ерозія та природне руйнування схилів у процесі вивітрювання порід), кліматичних (вплив вітру) чинників. Показано, що, незважаючи на те, що види роду не знищуються людиною, їхні популяції зазнають опосередкованого впливу негативних для виду антропогенних і природних чинників, які негативно впливають на життєздатність локальних ценопопуляцій. У зв'язку із цим, доцільно перевести видовий комплекс з категорії "неоцінений" у Червоній книзі України до категорії "вразливий". Для подальшої оптимізації збереження цього видового комплексу в різних локалітетах і оселищах доцільно розробити відповідні природоохоронні менеджмент-плани за прикладом НПП "Подільські Товтри". У рамках таких менеджментпланів слід урахувати наукові, організаційно-природоохоронні, еколого-просвітницькі та інтродукційні заходи.

Ключові слова: охоронна оцінка, стан популяцій, антропогенні та природні чинники, Schivereckia podolica, Schivereckia mutabilis, збереження
Кагало А. ${ }^{1}$, Колодий В. ${ }^{2}$, Любинская Л. ${ }^{2}$ Созологическая оценка, перспективы и методы сохранения видов рода Schivereckia (Draba s. l.; Brassicaceae) в Украине. Укр. бот. журн., 2018, 75(2): 169-178.

${ }^{1}$ Институт экологии Карпат НАН Украины ул. Козельницкая, 4, Львов 79026, Украина

${ }^{2}$ Каменец-Подольский национальный университет имени Ивана Огиенко

ул. Огиенко, 61, Каменец-Подольский 32301 , Хмельницкая обл., Украина

На основании обобщения материалов многолетних исследований состояния популяций и местообитаний видов рода Schivereckia (Brassicaceae) - Schivereckia podolica и $S$. mutabilis (= S. podolica s. 1.) в Украине даны оценка их состояния, охранного статуса и рекомендации для оптимального сохранения. Показано, что популяции вида испытывают негативное влияние как антропогенных (засорение экотопов бытовым мусором, заливка канализационными стоками, выпас, вытаптывание, выжигание, взрывные работы, механическое разрушение экотопов вследствие добычи известняка, щебня), так и естественных (ценотических (уменьшение конкурентной способности), биологических (уменьшение жизненности популяции), физических (водная эрозия и естественное разрушение склонов в процессе выветривания пород), климатических (влияние ветра) факторов. Показано, что, несмотря на то, что виды рода не уничтожаются человеком, их популяции испытывают опосредованное влияние негативных для вида антропогенных и природных факторов, что влияет на жизнеспособность локальных ценопопуляций. В связи с этим, целесообразно перевести этот видовой комплекс из категории "неоцененный" в Красной книге Украины в категорию "уязвимый". Для дальнейшей оптимизации сохранения этого видового комплекса в различных локалитетах и местообитаниях целесообразно разработать соответствующие природоохранные менеджмент-планы по примеру НПП "Подольские Товтры". В рамках таких менеджмент-планов следует учесть научные, организационно-природоохранные, эколого-просветительские и интродукционные мероприятия.

Ключевые слова: охранная оценка, состояние популяций, антропогенные и природные факторы, Schivereckia podolica, Schivereckia mutabilis, охрана 